\title{
Does gender affect immune response in HIV patients?
}

\section{Gülçin Şahingöz Erdal $\square \mathbb{O}^{1}$, Nilgün Işıksaçan $\square \mathbb{O}^{2}$, Ramazan Korkusuz $\square \mathbb{D}^{3^{*}}$, Pınar Kasapoğlu $\square \mathbb{D}^{2}$, Kadriye Kart Yaşar $\square \mathbb{D}^{3}$}

1 Department of Internal Medicine, Bakirkoy Dr. Sadi Konuk Training and Research Hospital, Istanbul, Turkey

2 Department of Biochemistry, Bakirkoy Dr. Sadi Konuk Training and Research Hospital, Istanbul, Turkey

3 Infectious Diseases and Clinical Microbiology, Bakirkoy Dr. Sadi Konuk Training and Research Hospital, Istanbul, Turkey.

\begin{abstract}
Gender differences affect the frequency and course of many diseases. This study aimed to determine the gender distribution in HIV-infected patients and investigate the relationship between gender and immune response. The study included HIV-infected patients who followed up in our hospital in 2018. The patients were divided into HIV RNA negative patients (Group 1) and HIV RNA positive patients (Group 2). Patients with diseases that may affect the immune system and those using drugs that affect the immune system were excluded from the study. The evaluation was made of 549 patients, as 305 patients (45 females $14.75 \%$ ) in Group 1 and 224 patients (23 females, 9.43\%) in Group 2. When the CD4/CD8 ratio of male and female patients was compared in both groups, a lower rate was determined in females $(0.71-0.58)$ than males $(0.82-0.93)$. A negative correlation was determined between HIV RNA and the CD4/CD8 ratio in premenopausal females $(p=0.045)$ and males $(\leq 45$ years $p=0.0001)$. Clinical studies of HIV infection have demonstrated better initial viremia control in females with primary infection, faster disease progression, and stronger immune activation than males for the same level of viral replication.
\end{abstract}

Keywords: HIV; AIDS; Gender; Immune Response.

\section{INTRODUCTION}

Approximately 38 million people worldwide are infected with the human immunodeficiency virus (HIV). As most of these individuals do not have access to appropriate treatment, HIV infection eventually leads to serious immune deficiency, resulting in a condition called AIDS (Acquired Immune Deficiency Syndrome), resulting in morbidity and mortality., $, 2,3$ However, the CD4: CD8 ratio is usually less than 1 in HIV infection. The primary mechanism leading to immunodeficiency, opportunistic infections, and ultimately death in HIV infection is the continuous loss of CD4 T cells. ${ }^{4}$

Gender differences affect the incidence and course of many diseases. Gonadal sex steroids are particularly focused on gender-specific risk factors. ${ }^{5} \mathrm{~A}$ combination of environmental factors, host genetics, and viral characteristics determines transmission and pathogenesis in HIV infection. ${ }^{6}$ The objective of this study was to determine the gender distribution in patients infected with HIV

\footnotetext{
Corresponding author.

E-mail address: ramazankorkusuz98@gmail.com (Ramazan Korkusuz)

DOI: 10.29238/teknolabjournal.v10i1.261

Received 06 February 2021; Received in revised form 20 March 2021: Accepted 01 April 2021

(C) 2021 The Authors. Published by Poltekkes Kemenkes Yogyakarta Indonesia.

This is an open-access article under the CC BY-SA license.
} 
In Istanbul, the most populous city in Turkey, and to investigate the relationship between gender and immune response in this patient group.

\section{MATERIAL AND METHOD}

Approval for this retrospective study was granted by the Local Ethics Committee(2019-18/16.09.2019). The study included HIV-infected patients who followed up in our hospital in 2018. The patients were divided into HIV RNA negative (Group 1) and HIV RNA positive patients (Group 2). Patients were divided into two groups as under 45 age and 45 and above age according to sex hormones effects. Patient information was obtained from the hospital data system and immunology laboratory. The informed consent form was not obtained from the patients due to the retrospective study. The identity of the patients or the information to disclose their identity was never used, and all patient data was stored in encrypted files on personal computers. Patients were excluded if they were aged $<18$ years, pregnant, had any disease affecting the immune system, a diagnosed malignancy, chronic renal failure, receiving estrogen-progesterone or androgen-containing hormone therapy, or if they were receiving estrogenprogesterone or androgen-containing were taking drugs that could affect the immune system. Flow cytometric analyses were performed with Navios cytometer (BECLS)-Kaluza Software. Whole blood was stained with antihuman FITC-CD45, PE-CD4, ECD-CD8, PE-CY5.5-CD3 (Beckman Coulter, Brea, California) antibodies. The percent and count of CD4+ and CD8+ cell are expressed CD3+CD4+ and CD3+CD8+ cells in CD45+ leukocyte gating. The HIV RNA level was measured with the PCR method (Real-time PCR, Rotor gene $Q$, QIAGEN, Germany).

Statistical analyses were performed using NCSS 11 software (Number Cruncher Statistical System, 2017 Statistical Software). Chi-square analysis was applied to determine relationships between categorical variables. The Independent Samples t-test was used to compare two groups of continuous independent variables with normal distribution. The Mann-Whitney $U$ test was used to compare two independent groups of variables that did not fulfill the normal distribution assumption. Spearman correlation analysis was applied to determine the correlational relationships between variables that did not meet the normal distribution assumption. A value of $p<0.05$ was considered statistically significant.

\section{RESULTS AND DISCUSSION}

The evaluation was made of a total of 549 patients, comprising 68 females and 481 males. Group 1 included 305 patients (45 females, 14.75\%) HIV RNA negative after appropriate antiretroviral therapy (ART). Group 2 included 224 patients (23 females, 9.43\%) who had not yet received treatment or had not completed treatment and were HIV RNA positive. In both groups, there was no significant age difference between male and female patients (Table 1). When the female patients were evaluated alone, WBC, CD4 T cells, and CD4 / CD8 values were lower, and lymphocyte and CD8 T cells values were higher in Group 2, although not statistically significant (Table 2). The CD4 / CD8 ratio was $0.71 \pm$ 0.56 in Group 1 and $0.58 \pm 0.47$ in Group 2 ( $p>0.05)$. When the male patients have evaluated alone, WBC and CD4 cells values were significantly lower ( $p$ $<0.0001)$, and CD8\% and CD4 / CD8 values were significantly higher ( $<<0.0001)$ in Group 2 (Table 3). The CD4 / CD8 ratio was $0.82 \pm 0.9$ in Group 1 and $0.93 \pm$ 6.64 in Group 2 ( $p<0.0001)$. The CD4 / CD8 ratio of female and male patients in Group 1 was compared; the CD4 / CD8 ratio in females was $0.71 \pm 0.56$, which 
was lower than that of males $(0.82 \pm 0.9)$. The ratio in patients in Group 2 was similar to that in Group 1, with a CD4 / CD8 ratio of $0.58 \pm 0.47$ in females and lower than in males $(0.93 \pm 6.64)$. A significant negative correlation was determined between HIV RNA and the CD4 T cells in premenopausal women ( $p$ $=0.005, r=-0.700)$ and males $(\leq 45$ years $p<0.0001, r=-0.322,>45$ years $p<$ $0.001, r=-0.486)$. There was a positive correlation between HIV RNA and the CD8 $T$ cells in males (45 years $p=0.022, r=0.178$ ). A significant negative correlation was determined between HIV RNA and the CD4 / CD8 ratio in premenopausal women $(p=0.045, r=-0.542)$ and males $(\leq 45$ years $p=0.0001$, $r=-0.486,>45$ years $p=0.001, r=-0.447$ ) (Table 4). When the RNA count was compared in Group 2, the median RNA value was lower in females than in males (433-655 copy/ml) (Table 5).

The progression of the disease in HIV infection is determined by the number and percentage of CD4 T cells. CD4 is a Tcell helper T cell and regulates the immune response by interacting with other immune cells via inflammatory cytokines such as interleukin-1 (IL-1), IL-6, or tumor necrosis factor $\alpha$ (TNF-a),,$\underline{7}$ Specific cytotoxic CD8 Tcells recognize virus antigens on the surface of HIVinfected cells and need help in immunological memory and the cytolytic response of CD4 $\mathrm{T}$ cells while killing cells by lysis through antigen-specific cytotoxic mechanisms. $\stackrel{9}{ }$

In the early stage of infection with HIV, CD8 T cells initiate a severe specific HIV response and increase in number by approximately 20 -fold. Specific anti-HIV cytotoxic CD8 + T cells are present even before specific antibodies are detected. $\frac{10}{1}$ In acute infection, most of the cells in the immune response become active and contribute to infection progression. In the current study, CD8+ T cells levels were high in both male and female patients in the group with acute HIV infection (Group 2). CD8 + T cells exhibit antiviral activity with soluble factors that inhibit the HIV replication they secrete and with their HIV-specific cytotoxins. ${ }^{11}$

The absolute number of CD4 T cells is considered the main criterion in determining the risk of opportunistic infection, deciding to initiate ART, and predicting AIDS-related cancers and deaths. However, the CD4 / CD8 ratio is also used as a parameter to predict prognosis. $\frac{12,13}{1 n}$ the general population, a CD4 / CD8 ratio of $<1.0$ is considered the predictor of immunosenescence and is an independent predictor of overall mortality. $\frac{14}{4}$

Studies have shown that in both HIV-infected and non-HIV-infected populations, females have higher CD4 cell counts than males. $\frac{15,16}{2 a p a t a}$ et al. showed that the CD4 / CD8 ratio of male patients was lower than that of females, regardless of age and duration of treatment. ${ }^{17}$ However, in contrast to that study, the CD4 / CD8 ratios were higher in males in both Group 1 and Group 2 in the current study. In a long-term cohort study by Sacarino et al., multivariate analyses including age, sex, rare CD4, CD4 Tcell count, and ART duration were performed in 407 patients to predict non-AIDS events, including malignancies, cardiovascular and renal diseases. A low CD4 / CD8 ratio was an independent factor for both non-AIDS morbidity and mortality in long-term HIV-positive patients independent of the absolute CD4 T cell count. ${ }^{18}$ As the current study did not include long-term follow-up data, no comment on mortality and morbidity can be made. All these studies show that the CD4 T cell number has lost its predictive value, while the CD4 / CD8 ratio remains a predictor of morbidity and mortality associated with AIDS or not, even after prolonged ART. $\stackrel{19}{ }$

The incidence, severity, and course of some diseases may be different for men, and women. $\underline{20}$ Autoimmune diseases, in particular, are more common in females. ${ }^{21}$ In addition, the incidence, and severity of many microbial infections, including malaria and tuberculosis, ${ }^{22}$ influenza,,$\frac{23}{}$ hepatitis ${ }^{24}$, and HIV, have been reported to differ between the genders. ${ }^{25}$ In the current study, $87.64 \%$ ( $\left.n: 481\right)$ of the patients who were followed up for HIV infection and included in the study 
within one year were male, and there was a statistically significant male predominance in the current patient population. In HIV infection, clinical research has shown that females have faster disease progression and stronger immune activation than males for the same level of viral replication and better control of the first viremia in women during primary infection. $\frac{26}{\text { In }}$ the current study patient population, $66,17 \%$ ( $n: 45)$ of the female patients had viremia control, and HIV RNA was negative, whereas this rate was $54.05 \%$ ( $\mathrm{n}: 260$ ) for males, similar to the above-mentioned study.

Despite advances in the pathogenesis and treatment of HIV infection, the biological mechanisms leading to gender-specific differences have not been fully elucidated. Gender-specific environmental risk factors, differences in the microbiome by sex, ${ }^{27}$ steroid hormones secreted by gonads ${ }^{\underline{28}}$, and the direct effects of $X$ and $Y$ chromosome-related factors ${ }^{29}$ may be responsible for this. Of these factors, gonadal sex steroids have mainly been focused on.

The level of immune activation is an essential predictor of the course of HIV disease. $\underline{30}$ The level of immune activation contributes to the progression of HIV disease and has been shown to differ between males and females. $\underline{28}$

In a multi-center cohort study that included many countries such as the United States of America, Australia, Canada, and Brazil, it was seen that in primary HIV infection, females tend to have lower plasma viral load levels than men. $\frac{31}{}$ Similarly, in the current study patient population, the viral load in female patients in Group 2 was much lower than in male patients. Another study stated that the risk of developing AIDS was 1.6 times higher in HIV-infected females with the same viral load as males. $\frac{32}{2}$ In the current study, as the HIV RNA increased in premenopausal patients, the CD4 / CD8 ratio decreased, and the absence of this decrease in postmenopausal women supports this view. Differences in immunoreaction in reproductive and postmenopausal periods in women suggest that sex-related changes in HIV infection may be due to gonadal sex hormones in the foreground. Sex hormones can affect the susceptibility of CD4 T cells to infection by altering the density of coreceptors and receptors in the target cells. The effects of progesterone on human cervical cells have also been investigated and shown to increase expression of HIV receptors CD4, CCR5, and CXCR4 in cervical CD4 + T cells. $\frac{33}{}$

\section{CONCLUSION}

Clinical studies of HIV infection have demonstrated better initial viremia control in females with primary infection, faster disease progression, and stronger immune activation than males for the same level of viral replication. Further studies are needed to clarify the role of gender in HIV pathogenesis. Particular focus on gonadal sex steroids in the pathogenesis may be of guidance for new trends in preventing or treating HIV infection.

\section{AUTHORS' CONTRIBUTIONS}

Gülçin Şahingöz Erdal : Conceived, designed the review, and wrote the manuscript.

Ramazan Korkusuz : Performed the search of articles and gathered the information and valid biomarkers from the articles, and wrote the manuscript.

Pınar Kasapoğlu Performed the search of articles.

Nilgün Işıksaçan

Read the literature and applied the exclusion criteria, and interpret the data.

Kadriye Kart Yaşar : Substantial contribution to the interpretation of data. 
All authors critically revised the manuscript for important intellectual content, approved the final version to be submitted, and agreed to be accountable for the manuscript's content.

\section{FOUNDING INFORMATION}

This research received no specific grant from any funding agency in public, commercial or not-for-profit sectors.

\section{DATA AVAILABILITY STATEMENT}

The utilized data to contribute to this investigation are available from the corresponding author on reasonable request.

\section{DISCLOSURE STATEMENT}

The views and opinions expressed in this article are those of the authors and do not necessarily reflect the official policy or position of any affiliated agency of the authors. This article was previously presented as an oral presentation at the "25th National Immunology Congress".

\section{REFERENCE}

1. Gonzalo-Gil E, Ikediobi U, Sutton RE. Mechanisms of Virologic Control and Clinical Characteristics of HIV+ Elite/Viremic Controllers. Yale J Biol Med. 2017;90(2):245-259. http://www.ncbi.nlm.nih.gov/pubmed/28656011.

2. Miceli $M C$, von Hoegen $P$, Parnes JR. Adhesion versus coreceptor function of CD4 and CD8: role of the cytoplasmic tail in coreceptor activity. Proc Natl Acad Sci $U$ S A. 1991;88(7):2623-2627. doi:10.1073/pnas.88.7.2623.

3. Margolick JB, Gange SJ, Detels R, O'Gorman MRG, Rinaldo CR, Lai S. Impact of inversion of the CD4/CD8 ratio on the natural history of $\mathrm{HIV}-1$ infection. J Acquir Immune Defic Syndr. 2006;42(5):620-626. doi:10.1097/01.qai.0000223028.55080.9d.

4. O'Brien WA, Hartigan PM, Martin D, et al. Changes in plasma HIV-1 RNA and CD4+ lymphocyte counts and the risk of progression to AIDS. Veterans Affairs Cooperative Study Group on AIDS. $N$ Engl $\mathrm{J}$ Med. 1996;334(7):426-431. doi:10.1056/NEJM199602153340703.

5. Seillet $C$, Laffont $S$, Trémollières $F$, et al. The TLR-mediated response of plasmacytoid dendritic cells is positively regulated by estradiol in vivo through cell-intrinsic estrogen receptor a signaling. Blood. 2012;119(2):454-464. doi:10.1182/blood-2011-08-371831.

6. Mefod'ev $\mathrm{V} V$, lastrebov AF. [Role of agricultural animals in the development of anthropo-pathogenic foci of leptospirosis]. Zhurnal Mikrobiol Epidemiol $i \quad$ Immunobiol. 1965;42(3):142. http://www.ncbi.nlm.nih.gov/pubmed/5882769.

7. Stacey AR, Norris PJ, Qin L, et al. Induction of a striking systemic cytokine cascade prior to peak viremia in acute human immunodeficiency virus type 1 infection, in contrast to more modest and delayed responses in acute hepatitis B and C virus infections. J Virol. 2009;83(8):3719-3733. doi:10.1128/JVI.01844-08.

8. Altfeld M, Rosenberg ES. The role of CD4(+) T helper cells in the cytotoxic T lymphocyte response to HIV-1. Curr Opin Immunol. 2000;12(4):375-380. doi:10.1016/s0952-7915(00)00103-5.

9. Schmitz JE, Kuroda MJ, Santra S, et al. Control of viremia in simian immunodeficiency virus infection by CD8+ lymphocytes. Science. 1999;283(5403):857-860. doi:10.1126/science.283.5403.857.

10. Koup RA, Safrit JT, Cao Y, et al. Temporal association of cellular immune responses with the initial control of viremia in primary human immunodeficiency virus type 1 syndrome. J Virol. 1994;68(7):4650-4655. 
doi:10.1128/JVI.68.7.4650-4655.1994.

11. Mackewicz CE, Ortega HW, Levy JA. CD8+ cell anti-HIV activity correlates with the clinical state of the infected individual. $J$ Clin Invest. 1991;87(4):1462-1466. doi:10.1172/JCI115153.

12. Clifford GM, Rickenbach M, Lise M, et al. Hodgkin lymphoma in the Swiss HIV Cohort Study. Blood. 2009;113(23):5737-5742. doi:10.1182/blood2009-02-204172.

13. Lang S, Mary-Krause M, Cotte $L$, et al. Impact of individual antiretroviral drugs on the risk of myocardial infarction in human immunodeficiency virus-infected patients: a case-control study nested within the French Hospital Database on HIV ANRS cohort CO4. Arch Intern Med. 2010;170(14):1228-1238. doi:10.1001/archinternmed.2010.197.

14. Hadrup SR, Strindhall J, Køllgaard T, et al. Longitudinal studies of clonally expanded CD8 $T$ cells reveal a repertoire shrinkage predicting mortality and an increased number of dysfunctional cytomegalovirus-specific T cells in the very elderly. J Immunol. 2006;176(4):2645-2653. doi:10.4049/jimmunol.176.4.2645.

15. Prins M, Robertson JR, Brettle RP, et al. Do gender differences in CD4 cell counts matter? AIDS. 1999;13(17):2361-2364. doi:10.1097/00002030199912030-00007.

16. Maini MK, Gilson RJ, Chavda N, et al. Reference ranges and sources of variability of CD4 counts in HIV-seronegative women and men. Genitourin Med. 1996;72(1):27-31. doi:10.1136/sti.72.1.27.

17. Rickabaugh TM, Jamieson BD. A challenge for the future: aging and HIV infection. Immunol Res. 2010;48(1-3):59-71. doi:10.1007/s12026-0108167-9.

18. Saracino A, Bruno G, Scudeller $L$, et al. Chronic inflammation in a longterm cohort of HIV-infected patients according to the normalization of the CD4:CD8 ratio. AIDS Res Hum Retroviruses. 2014;30(12):1178-1184. doi:10.1089/aid.2014.0080.

19. Lu W, Mehraj V, Vyboh K, Cao W, Li T, Routy J-P. CD4:CD8 ratio as a frontier marker for clinical outcome, immune dysfunction and viral reservoir size in virologically suppressed HIV-positive patients. J Int AIDS Soc. 2015;18:20052. doi:10.7448/IAS.18.1.20052.

20. van Lunzen J, Altfeld M. Sex differences in infectious diseases-common but neglected. J Infect Dis. 2014;209 Suppl:S79-80. doi:10.1093/infdis/iiu159.

21. Ngo ST, Steyn FJ, McCombe PA. Gender differences in autoimmune disease. Front Neuroendocrinol. 2014;35(3):347-369. doi:10.1016/i.yfrne.2014.04.004.

22. Nhamoyebonde S, Leslie A. Biological differences between the sexes and susceptibility to tuberculosis. J Infect Dis. 2014;209 Suppl:S100-6. doi:10.1093/infdis/jiu147.

23. Gabriel G, Arck PC. Sex, immunity and influenza. J Infect Dis. 2014;209 Suppl:S93-9. doi:10.1093/infdis/iiu020.

24. Baden R, Rockstroh JK, Buti M. Natural history and management of hepatitis C: does sex play a role? J Infect Dis. 2014;209 Suppl:S81-5. doi:10.1093/infdis/jiu057.

25. Addo MM, Altfeld M. Sex-based differences in HIV type 1 pathogenesis. $J$ Infect Dis. 2014;209 Suppl:S86-92. doi:10.1093/infdis/jiu175.

26. Ziegler S, Altfeld M. Sex differences in HIV-1-mediated immunopathology. Curr Opin HIV AIDS. 2016;11(2):209-215. doi:10.1097/COH.0000000000000237.

27. Yurkovetskiy L, Burrows M, Khan AA, et al. Gender bias in autoimmunity is influenced by microbiota. Immunity. 2013;39(2):400-412. doi:10.1016/j.immuni.2013.08.013. 
28. Meier A, Chang JJ, Chan ES, et al. Sex differences in the Toll-like receptor-mediated response of plasmacytoid dendritic cells to HIV-1. Nat Med. 2009;15(8):955-959. doi:10.1038/nm.2004.

29. Markle JG, Fish EN. Sex matters in immunity. Trends Immunol. 2014;35(3):97-104. doi:10.1016/j.it.2013.10.006.

30. Lawn SD, Butera ST, Folks TM. Contribution of immune activation to the pathogenesis and transmission of human immunodeficiency virus type 1 infection. Clin Microbiol Rev. 2001;14(4):753-777, table of contents. doi:10.1128/CMR.14.4.753-777.2001.

31. Meditz AL, MaWhinney S, Allshouse A, et al. Sex, race, and geographic region influence clinical outcomes following primary HIV-1 infection. $J$ Infect Dis. 2011;203(4):442-451. doi:10.1093/infdis/iiq085.

32. Farzadegan $\mathrm{H}$, Hoover DR, Astemborski J, et al. Sex differences in HIV-1 viral load and progression to AIDS. Lancet (London, England). 1998;352(9139):1510-1514. doi:10.1016/S0140-6736(98)02372-1.

33. Patterson BK, Landay A, Siegel JN, et al. Susceptibility to human immunodeficiency virus-1 infection of human foreskin and cervical tissue grown in explant culture. Am $J$ Pathol. 2002;161(3):867-873. doi:10.1016/S0002-9440(10)64247-2.

Table 1. Gender Distribution of the Groups

\begin{tabular}{cccc}
\hline \multirow{2}{*}{ Gender } & Group 1 & Group 2 & p-value \\
\cline { 2 - 3 } & $\mathrm{n}(\%)$ & $\mathrm{n}(\%)$ & \\
\hline Female & 45 & 23 & \multirow{2}{*}{0.060} \\
Male & 260 & 221 & \\
\hline \multicolumn{4}{c}{ Chi-square test } \\
\hline
\end{tabular}

Table 2. Comparison of Variables of Female Patients According to Groups

\begin{tabular}{|c|c|c|c|}
\hline Female & $\begin{array}{c}\text { Group } 1 \\
n=45\end{array}$ & $\begin{array}{c}\text { Group } 2 \\
n=23 \\
\text { Mean } \pm S D \\
\text { Med. (Min.-Max.) } \\
\end{array}$ & p-value \\
\hline Age (years) & $\begin{array}{c}42.31 \pm 9.3 \\
41-(26-65)\end{array}$ & $\begin{array}{c}41.39 \pm 13.52 \\
38-(18-61)\end{array}$ & 0.673 \\
\hline white blood cell $10^{\star} 3 / u l$ & $\begin{array}{c}6542.89 \pm 2159.65 \\
6650-(2670-11410)\end{array}$ & $\begin{array}{c}6070 \pm 1472.41 \\
6240-(3710-9120)\end{array}$ & 0.292 \\
\hline Lymphocytes \% & $\begin{array}{c}31.82 \pm 9.38 \\
32.3-(8.9-51.7)\end{array}$ & $\begin{array}{c}34.56 \pm 8.62 \\
36.8-(20.6-51)\end{array}$ & 0.247 \\
\hline CD3+ & $\begin{array}{c}74.34 \pm 11.12 \\
76.3-(48.7-92)\end{array}$ & $\begin{array}{c}74.53 \pm 11.55 \\
76.9-(49.8-92.8)\end{array}$ & 0.945 \\
\hline$\%$ CD3+CD4+ & $\begin{array}{c}26.08 \pm 11.63 \\
26.4-(1.53-56.2)\end{array}$ & $\begin{array}{c}22.57 \pm 12.43 \\
20.8-(1.4-42.9)\end{array}$ & 0.291 \\
\hline CD3+CD4+ Cell/ul & $\begin{array}{l}545.62 \pm 319.97 \\
514-(11-1432)\end{array}$ & $\begin{array}{l}508.04 \pm 345.53 \\
503-(20-1230)\end{array}$ & 0.657 \\
\hline$\% C D 3+C D 8+$ & $\begin{array}{c}43.44 \pm 12.22 \\
44.1-(19.2-72.9)\end{array}$ & $\begin{array}{c}47.47 \pm 13.98 \\
47.3-(25.4-72)\end{array}$ & 0.224 \\
\hline CD3+CD8+ Cell/ul & $\begin{array}{c}873.87 \pm 401.49 \\
882-(144-2022)\end{array}$ & $\begin{array}{l}1029.22 \pm 504.27 \\
823-(431-2284)\end{array}$ & 0.484 \\
\hline CD4/CD8 & $\begin{array}{c}0.71 \pm 0.56 \\
0.51-(0.03-2.32)\end{array}$ & $\begin{array}{c}0.58 \pm 0.47 \\
0.47-(0.02-1.64)\end{array}$ & 0.235 \\
\hline \multicolumn{4}{|c|}{$\begin{array}{c}\text { Mann Whitney U test } \\
\text { Independent Samples t-test }\end{array}$} \\
\hline
\end{tabular}


Table 3. Comparison of Variables of Male Patients According to Groups

\begin{tabular}{|c|c|c|c|}
\hline Male & $\begin{array}{c}\text { Group 1 } \\
\mathrm{n}=260 \\
\text { Mean } \pm \text { SD } \\
\text { Med. (Min.-Max.) }\end{array}$ & $\begin{array}{c}\text { Group } 2 \\
\mathrm{n}=221 \\
\text { Mean } \pm \text { SD } \\
\text { Med. (Min.-Max.) }\end{array}$ & p-value \\
\hline Age (years) & $\begin{array}{c}38.11 \pm 11.87 \\
36-(18-70)\end{array}$ & $\begin{array}{c}37.18 \pm 11.28 \\
35-(18-69)\end{array}$ & 0.437 \\
\hline white blood cell $10^{\star} 3 / \mathrm{ul}$ & $\begin{array}{c}7350.04 \pm 2081.98 \\
7080-(3620-16980)\end{array}$ & $\begin{array}{c}6548.42 \pm 1959.86 \\
6290-(2270-13470)\end{array}$ & $<0.0001^{*}$ \\
\hline Lymphocytes \% & $\begin{array}{c}34.48 \pm 9.03 \\
34.8-(6.2-67.2)\end{array}$ & $\begin{array}{c}33.15 \pm 10.05 \\
32.4-(6.6-67.1)\end{array}$ & 0.129 \\
\hline CD3 Cell/ul & $\begin{array}{c}75.77 \pm 8.57 \\
76-(50.1-96.4)\end{array}$ & $\begin{array}{c}77.02 \pm 10.36 \\
78.4-(32-96.5)\end{array}$ & 0.133 \\
\hline$\% \mathrm{CD} 3+\mathrm{CD} 4+$ & $\begin{array}{c}28.39 \pm 9.83 \\
28.1-(0.9-56.4)\end{array}$ & $\begin{array}{c}20.88 \pm 9.67 \\
19.8-(0.76-46.9)\end{array}$ & $<0.0001^{*}$ \\
\hline CD3+CD4+ Cell/ul & $\begin{array}{l}697.62 \pm 309.38 \\
672-(11-1703)\end{array}$ & $\begin{array}{c}452.86 \pm 266.93 \\
431-(2-1531)\end{array}$ & $<0.0001^{*}$ \\
\hline \%CD3+CD8+ & $\begin{array}{c}41.64 \pm 11.53 \\
41.5-(16.9-83)\end{array}$ & $\begin{array}{c}51.55 \pm 29.69 \\
49.6-(16.6-447)\end{array}$ & $<0.0001^{*}$ \\
\hline CD3+CD8+ Cell/ul & $\begin{array}{c}1025.08 \pm 528.43 \\
871-(10.56-3826)\end{array}$ & $\begin{array}{l}1076.3 \pm 553.59 \\
961-(129-4051)\end{array}$ & 0.259 \\
\hline CD4/CD8 & $\begin{array}{c}0.82 \pm 0.9 \\
0.67-(0.01-13)\end{array}$ & $\begin{array}{l}0.93 \pm 6.64 \\
0.4-(0-99)\end{array}$ & $<0.0001^{*}$ \\
\hline & $\begin{array}{l}\text { Mann Whit } \\
\text { * Independent }\end{array}$ & t-test & \\
\hline
\end{tabular}

Table 4. Relationships between variables with HIV RNA level according to the age limit of 45 years in males and females (Group 1)

\begin{tabular}{|c|c|c|c|c|c|}
\hline \multirow[t]{2}{*}{ o } &  & \multicolumn{2}{|c|}{ Female } & \multicolumn{2}{|c|}{ Male } \\
\hline & & $\leq 45$ years & $>45$ years & $\leq 45$ years & $>45$ years \\
\hline \multirow{3}{*}{ CD4/CD8 } & $\mathbf{r}$ & $-0.542^{*}$ & 0.083 & -0.486 & $-0.447^{*}$ \\
\hline & $p$ & 0.045 & 0.831 & 0 & 0.001 \\
\hline & $\mathbf{n}$ & 14 & 9 & 165 & 56 \\
\hline
\end{tabular}

Table 5.Examination of HIV RNA positive cases by Gender

\begin{tabular}{lccc}
\hline & $\begin{array}{c}\text { Female } \\
(\mathbf{n}=23) \text { Mean } \pm \text { SD } \\
\text { Med. (Min.-Max.) }\end{array}$ & $\begin{array}{c}\text { Male } \\
(\mathbf{n}=221) \text { Mean } \pm \text { SD } \\
\text { Med. (Min.-Max.) }\end{array}$ & p-value \\
\hline HIV RNA & $45230 \pm 1460$ & $200842106 \pm 2962484$ & 0.506 \\
Copy/ml & $433-(27-695017)$ & $655-(5-44041392)$ & 0 \\
\hline \multicolumn{4}{c}{ Mann Whitney U test } \\
\hline
\end{tabular}

